\title{
TRACKING OF NUTRITIONAL STATUS BETWEEN CHILDHOOD AND ADOLESCENCE IN SCHOOLCHILDREN
}

\author{
TRACKING DO ESTADO NUTRICIONAL ENTRE A INFÂNCIA EA ADOLESCÊNCIA EM ESCOLARES
}

IgINAL ARTICLE

TRACKING DEL ESTADO NUTRICIONAL ENTRE LA INFANCIA Y LA ADOLESCENCIA EN ESCOLARES

Original Article

ARtigo Original

Artículo Original

Taciane Gomes do Prado' (Physical Educator)

Julio Cesar da Costa (Physical Educator)

Maria Raquel de Oliveira Bueno (Physical Educator)

Mariana Biagi Batista²

(Physical Educator)

Marcelo Romanzini' ${ }^{1}$ (Physical Educator)

Enio Ricardo Vaz Ronque ${ }^{1}$

(Physical Educator)

1. Universidade Estadual de Londrina, Physical Education Graduate Studies Program, Londrina, PR, Brazil.

2. Universidade Federal do Mato Grosso do Sul - Campus Corumbá, Pioneiros, MS, Brazil.

\section{Correspondence:}

Enio Ricardo Vaz Ronque Laboratório de Atividade Física e Saúde. Centro de Educação Física e Esporte. Rodovia Celso Garcia Cid, Km 380, Campus Universitário, Caixa Postal: 10.011, Sala 920, Londrina, PR, Brazil. 86057-970. enioronque@uel.br

\section{ABSTRACT}

Introduction: In view of the growing prevalence of childhood excess weight and obesity in Brazil in recent decades, it is necessary to observe how this phenomenon occurs in the period of transition to adolescence. Objective: To verify the tracking of excess weight between childhood and adolescence in schoolchildren of both sexes. Methods: The study has a longitudinal design and the data used are part of a prospective study carried out from 2002 to 2005. Participants included 397 schoolchildren of both sexes (211 boys and 186 girls). The nutritional status was determined by the body mass index, and the participants were divided into the following groups: Normal Weight to Normal Weight, Normal Weight to Excess Weight, Excess Weight to Excess Weight, Excess Weight to Normal Weight. The tracking was analyzed using the intraclass correlation coefficient (ICC) and Kappa ( $k$ ) index. Results: A significant difference $(P<0.05)$ was observed between all variables (age and anthropometric indicators) between 2002 and 2005 for boys and girls. The ICC indicated tracking classified as high $(I C C=0.87)$ for the BMI values, and the tracking percentage showed that $87 \%$ of the subjects remained in the same category of normal weight and excess weight. The values of $k=0.68$ show good tracking $(P<0.001)$, indicating a strong maintenance of the subjects in the normal and excess weight categories. Conclusion: The tracking percentage was high, indicating that both boys and girls maintained the classification of excess weight during the period analyzed. Level of Evidence ll; Lesser quality prospective study (eg, patients enrolled at different points in their disease or $<80 \%$ followup).

Keywords: Longitudinal studies; Overweight; Child; Adolescent.

\section{RESUMO}

Introdução: Tendo em vista a crescente prevalência de sobrepeso e obesidade na infância no Brasil nas últimas décadas, é preciso observar como esse fenômeno ocorre no período de transição para a adolescência. Objetivo: Verificar o tracking do excesso de peso entre a infância e a adolescência em escolares de ambos os sexos. Métodos: Trata-se de estudo longitudinal e os dados utilizados fazem parte de um estudo prospectivo, realizado no período de 2002 a 2005. Participaram 397 escolares de ambos os sexos (211 meninos e 186 meninas). O estado nutricional foi determinado pelo índice de massa corporal, e os participantes foram divididos nos seguintes grupos: Peso Normal para Peso Normal, Peso Normal para Excesso de Peso, Excesso de Peso para Excesso de Peso, Excesso de Peso para Peso Normal. O tracking foi analisado pelo coeficiente de correlação intraclasse (CCl) e do índice Kappa (k). Resultados: Observou-se diferença significativa $(P<0,05)$ entre todas as variáveis (idade e indicadores antropométricos) entre 2002 e 2005 para meninos e meninas. Com relação aos valores de IMC, o CCl indicou tracking classificado como alto $(\mathrm{CCl}=0,87)$ e o percentual de tracking mostrou que $87 \%$ dos sujeitos permaneceram na mesma categoria de peso normal e excesso de peso. Os valores de $k=0,68$ demonstram um bom tracking $(P<0,001)$, indicando uma forte manutenção dos sujeitos nas categorias de peso normal e excesso de peso. Conclusão: O percentual do tracking foi elevado, indicando que tanto meninos quanto meninas mantiveram a classificação de excesso de peso durante o período analisado. Nível de Evidência ll; Estudo prospectivo de menor qualidade (por exemplo, pacientes inscritos em diferentes estágios da doença ou <80\% de acompanhamento).

Descritores: Estudos longitudinais; Sobrepeso; Criança; Adolescente.

\section{RESUMEN}

Introducción: Teniendo en vista la creciente prevalencia de sobrepeso y obesidad en la infancia en Brasil en las últimas décadas, es preciso observar cómo ese fenómeno ocurre en el período de transición para la adolescencia. Objetivo: Verificar el tracking del exceso de peso entre la infancia y la adolescencia en escolares de ambos sexos. Métodos: Se trata de estudio longitudinal y los datos utilizados forman parte de un estudio prospectivo, realizado en el período de 2002 a 2005. Participaron 397 escolares de ambos sexos (211 niños y 186 niñas). El estado nutricional fue determinado por el índice de mas a corporal, y los participantes fueron divididos en los siguientes grupos: Peso Normal para Peso Normal, Peso Normal para Exceso de Peso, Exceso de Peso para Exceso de Peso, Exceso de Peso para Peso Normal. El tracking fue analizado por el coeficiente de correlación intraclase (CCl) y del índice Kappa (k). Resultados: Se observó diferencia significativa $(P<0,05)$ entre todas las variables (edad e indicadores antropométricos) entre 2002 y 2005 para niños y niñas. Con relación a los valores de IMC, el CCl indicó tracking clasificado como alto $(C C l=0,87)$ y el porcentual de tracking mostró que $87 \%$ de los sujetos permanecieron en la misma categoría de peso normal y 
exceso de peso. Los valores de $k=0,68$ demuestran un buen tracking $(P<0,001)$, indicando un fuerte mantenimiento de los sujetos en las categorías de peso normal y exceso de peso. Conclusión: El porcentual del tracking fue elevado, indicando que tanto niños como niñas mantuvieron la clasificación de exceso de peso durante el período analizado. Nivel de Evidencia ll; Estudio prospectivo de menor calidad (por ejemplo, pacientes inscritos en diferentes etapas de la enfermedad o $\leq 80 \%$ de acompañamiento).

Descriptores: Estudios longitudinales; Sobrepeso; Niño; Adolescente.

\section{INTRODUCTION}

The prevalence of overweight is increasing globally in all age groups. This accumulation of irregular or excessive body fat can cause a number of health problems for the individuals, such as cardiovascular disease, diabetes, musculoskeletal disorders, metabolic syndrome, and some cancers ${ }^{1}$.

In the case of children and adolescents, this epidemic has generated great concern among professionals and researchers in the public health areas, since excess body fat favors the development and/or aggravation of numerous health risk factors such as high blood pressure, high fasting plasma glucose, high triglyceride concentrations, low concentrations of high density lipoprotein (HDL), and metabolic syndrome ${ }^{2}$, as well as the fact that excess body weight acquired during childhood and adolescence remains throughout adulthood ${ }^{3}$.

In this sense, some studies conducted in developed countries have observed the persistence and incidence of overweight and body size of children from birth to the end of early childhood at around seven years of age ${ }^{4,5}$. These so-called "tracking" studies have been defined as the maintenance or placement of an individual within a group over time, it being necessary to obtain information from at least two moments ${ }^{6}$.

In Brazil, a survey conducted in different regions with a sample of children and adolescents, aged between six and 17 years, indicated that $27.6 \%$ of the boys and $33.8 \%$ of the girls presented excess weight ${ }^{7}$. Additionally, another study showed a high rate of excess body weight (30\%) in a survey with Brazilian students between 2009 and 2012 ${ }^{8}$, however, this information was produced from cross-sectional data.

Considering the above, observing changes in the body mass index (BMI) in the period from childhood to adolescence is necessary and, for this reason, the relevance of tracking studies should be considered for the screening of overweight, making it possible to understand individual peculiarities for the increase or maintenance of body weight and the persistence of these factors over time ${ }^{9}$.

In addition, another important aspect observed in Brazil is that overweight may be associated with socioeconomic factors ${ }^{10}$, and the prevalence of overweight was from $3 \%$ to $21 \%$ in children of high socioeconomic status $^{11}$. In studies conducted in public and private schools, a higher prevalence of excess weight was observed for schoolchildren in private networks when compared to their peers in the public sector ${ }^{12}$.

Therefore, the objective of this study was to verify the tracking of nutritional status between childhood and adolescence in students of high socioeconomic level.

\section{METHODS}

\section{Study design and sample selection}

The data used in this study are part of a prospective study entitled "Analysis of growth and health related physical fitness in high socioeconomic level students", where the objective was to verify the tracking of physical fitness related to health during the transition between childhood and the beginning of adolescence. To obtain the initial data, a survey was carried out (year 2002) of the number of schoolchildren enrolled in the private education network in the city of Londrina, according to the Regional Education Center of the State of Paraná Department of Education. Next, the equation proposed by Barbetta ${ }^{13}$ was applied for simple random sampling, using a 95\% alpha, with an 80\% power and a sampling error of 5\%, giving an estimate of 363 subjects. Subsequently, a school in the central region was chosen as it met the criteria proposed by the research, presenting a low transfer rate of students in the previous year.

\section{Subjects}

In 2002, 510 students aged seven to 10 years, followed annually in 2003, 2004, and 2005 with five age overlaps (eight, nine, 10, 11, and 12 years) were evaluated. At the final moment (2005), 397 schoolchildren (211 boys and 186 girls), aged between 10 and 13 years, were analyzed, due to the sample loss of $25 \%$ after four years of follow-up. The study was approved by the Ethics Committee for Research involving humans, opinion number 024/03. After explaining the study proposal and procedures to be performed, those responsible for the children signed the informed consent form.

\section{Anthropometric measurements}

Body mass was measured on a digital platform scale, Filizola brand, with an accuracy of $0.5 \mathrm{~kg}$, and height using a wooden stadiometer with a precision of $0.1 \mathrm{~cm}$, according to the procedures described by Gordon et al. ${ }^{14}$. The body mass index (BMI) was determined by the body mass/ height ${ }^{2}$ ratio, the body mass being expressed in kilograms $(\mathrm{kg})$ and the height in meters (m). Twenty percent of the subjects were randomly selected, proportionally divided according to sex, to perform a second series of successive measures to verify the reproducibility of the anthropometric variables. To verify the extent of the error of the evaluator, the technical error of absolute (TEMa) and relative measurements (TEMr) were adopted, resulting in a TEMa of $0.33 \mathrm{~kg}$ and TEMr of $0.6 \%$ for body mass $(\mathrm{kg})$, and a TEMa of $0.48 \mathrm{~cm}$ and TEMr of $0.3 \%$ for height $(\mathrm{cm})$

\section{Classification of nutritional status}

The sex and age cut-off points proposed by the International Obesity Task Force (IOTF) ${ }^{15}$ were adopted to classify BMI values as normal weight and overweight, and for the purpose of analysis, subjects classified as overweight and obese were grouped into one group called excess weight (EW). To verify the extent of tracking, the subject BMls were categorized into groups: Normal Weight to Normal Weight (NW - NW), Normal Weight to Excess Weight (NW - EW), Excess Weight to Excess Weight (EW - EW), Excess Weight to Normal Weight (EW - NW).

\section{Statistical treatment}

For characterization of the sample, descriptive statistics were used, with values of mean and standard deviation. The comparison of the anthropometric indicators between 2002 and 2005 was verified by the dependent Student's t test. The tracking was analyzed using two statistical procedures: a) for the continuous values of the study variables, the intraclass correlation coefficient (ICC) was used with a $95 \% \mathrm{Cl}$, adopting values $<0.30$ as low; between 0.30 and 0.60 as moderate; and $>0.60$ as high ${ }^{16}$; b) to verify the strength of tracking agreement between the proportions of the subjects 
who maintained or changed classification during the follow-up period, the Kappa ( $k$ ) index was used according to the interpretation: $k \leq 0.20$, low; $k=0.21-0.40$, weak; $k=0.41-0.60$, moderate; $k=0.61-0.80$ good; and $k=0.81-1.00$ very good ${ }^{17}$. A 5\% level of significance was adopted. All statistical procedures were performed in the Statistical Package for the Social Sciences (SPSS for Windows Version 20.0).

\section{RESULTS}

The number of subjects who participated in the study at both moments was $n=397$, with 53\% boys $(n=211)$. The excess weight in 2002 was $28 \%$ and in $2005,27.5 \%$. Among the boys, the excess weight was in the order of $33 \%$ at both moments and for the girls was $24 \%$ and $21 \%$, in 2002 and 2005 respectively.

The characteristics of the sample, with values as mean and standard deviation and the differences between the means of the years 2002 (initial moment) and 2005 (final moment) are described in Table 1.

The student's t test indicated a significant difference $(P<0.05)$ between all variables between 2002 and 2005 for boys and girls, with special attention to the BMI variable, with a mean difference of $1.9 \mathrm{~kg} / \mathrm{m}^{2}$ for both sexes. The percentage differences between the BMI means in 2002 and 2005 were approximately $10 \%$ and $11 \%$, respectively, for boys and girls.

Table 2 presents the intraclass correlation coefficients (ICC) of the continuous BMI values between the initial and final moments, stratified by sex. For the BMI values between 2002 and 2005, the ICC indicated tracking classified as high for both sexes. For boys, the value was 0.88 ( $95 \%$ $\mathrm{Cl} 0.12-0.95)$ and for girls it was 0.86 (95\% Cl 0.28-0.96), demonstrating high maintenance of the relative position of the subjects in a group. All correlations were statistically significant $(P<0.05)$.

Table 3 presents the tracking values and agreement of normal weight and excess weight for both sexes. The percentage of tracking

Table 1.Characterization of the sample according to sex and moment of the study.

\begin{tabular}{c|c|c|c|c}
\hline Boys $(\mathbf{n = 2 1 1 )}$ & $\mathbf{2 0 0 2}$ & $\mathbf{2 0 0 5}$ & $\begin{array}{c}\text { Mean Difference } \\
\mathbf{2 0 0 5 - 2 0 0 2}\end{array}$ & $\mathbf{P}$ \\
\hline Chronological Age (years) & $9.0 \pm 1.2$ & $12.0 \pm 1.2$ & $3.0 \pm 1.8$ & $<0.001$ \\
\hline Body Mass (kg) & $33.9 \pm 9.2$ & $48.2 \pm 13.1$ & $14.3 \pm 5.5$ & $<0.001$ \\
\hline Height (cm) & $135.0 \pm 8.6$ & $154.0 \pm 10.6$ & $18.4 \pm 3.4$ & $<0.001$ \\
\hline BMl (Kg/m²) & $18.4 \pm 3.4$ & $20.2 \pm 3.9$ & $1.9 \pm 1.7$ & $<0.001$ \\
\hline Girls (n=186) & $\mathbf{2 0 0 2}$ & $\mathbf{2 0 0 5}$ & $\begin{array}{c}\text { Mean Difference } \\
\mathbf{2 0 0 5 - 2 0 0 2}\end{array}$ & $\mathbf{P}$ \\
\hline Chronological Age (years) & $9.0 \pm 1.1$ & $12.0 \pm 1.1$ & $3.0 \pm 0.1$ & $<0.001$ \\
\hline Body Mass (kg) & $32.1 \pm 8.1$ & $46.2 \pm 11.8$ & $14.1 \pm 5.2$ & $<0.001$ \\
\hline Height (cm) & $134.0 \pm 9.0$ & $152.7 \pm 9.6$ & $18.7 \pm 3.0$ & $<0.001$ \\
\hline BMl (Kg/m $\left./ \mathrm{m}^{2}\right)$ & $17.6 \pm 3.0$ & $19.6 \pm 3.6$ & $1.9 \pm 1.6$ & $<0.001$ \\
\hline
\end{tabular}

Note: $\mathrm{BMI}=$ Body Mass Index; $P=<0.05$.

Table 2. Intraclass correlation coefficient, 95\% confidence intervals of BMI between 2002 and 2005, according to sex.

\begin{tabular}{c|c|c|c|c}
\hline & ICC & Cl 95\% & P & Classification \\
\hline Girls & 0.86 & $(0.28-0.96)$ & $<0.001$ & High \\
\hline Boys & 0.88 & $(0.12-0.95)$ & $<0.001$ & High \\
\hline Total & 0.87 & $(0.21-0.96)$ & $<0.001$ & High \\
\hline
\end{tabular}

Table 3. Tracking of the nutritional status of the initial moment and after the period of follow-up according to sex.

\begin{tabular}{c|c|c|c}
\hline & $\begin{array}{c}\text { Boys } \mathbf{n = 2 1 1} \\
\mathbf{\%}(\mathbf{n})\end{array}$ & $\begin{array}{c}\text { Girls } \mathbf{n = 1 8 6} \\
\mathbf{\%}(\mathbf{n})\end{array}$ & $\begin{array}{c}\text { Total } \mathbf{n = 3 9 7} \\
\mathbf{\%}(\mathbf{n})\end{array}$ \\
\hline NW - NW & $61.1(129)$ & $70.4(131)$ & $65.5(260)$ \\
\hline NW - EW & $6.6(14)$ & $4.8(09)$ & $5.8(23)$ \\
\hline EW - EW & $26.5(56)$ & $16.1(30)$ & $21.7(86)$ \\
\hline EW - NW & $5.7(12)$ & $8.6(16)$ & $7.0(28)$ \\
\hline$\%$ Tracking & 87.6 & 86.5 & 87.2 \\
\hline Kappa & $0.72^{*}$ & $0.62^{*}$ & $0.68^{*}$ \\
\hline
\end{tabular}

NW - NW = Normal Weight to Normal Weight; NW - EW = Normal Weight to Excess Weight; EW - EW = Excess Weight to Excess Weight; EW - NW = Excess Weight to Normal Weight. ${ }^{*} P<0.001$. indicated that $87 \%$ of the subjects remained in the same classification category for normal weight and excess weight between childhood and adolescence. Of the total sample, $65 \%$ of the children who were considered normal weight remained in the same normal weight category after four years of follow-up and $22 \%$ of the subjects who were classified as excess weight during childhood remained in the same category in adolescence (Table 3).

On the other hand, it was found that approximately $6 \%$ of the children who were in the normal weight category in childhood moved to the excess weight category in adolescence, and, inversely, it was observed that $7 \%$ moved from the excess weight category to normal weight during the four years of follow-up.

According to the classification, it was possible to observe that the strength of agreement of excess weight during the four years of followup was considered high. Values of $k=0.68$ demonstrated good tracking $(P<0.001)$, indicating strong maintenance of the subjects in the categories of normal weight and excess weight; for boys and girls, respectively, with values of $k=0.72$ and $k=0.62(P<0.001)$.

\section{DISCUSSION}

This longitudinal study analyzed, in a sample of schoolchildren, the tracking of excess weight between the period of childhood and adolescence and showed that BMI stability and the percentage of tracking were high between the two periods (2002 to 2005). The importance of longitudinal surveys to verify the tracking of excess weight lies in the fact that the period of childhood or adolescence may increase the risk of cardiovascular diseases and all-cause mortality in adulthood ${ }^{18}$. Therefore, attempts to verify the magnitude of the persistence of excess weight between childhood, adolescence, and adulthood, have stimulated the development of investigations on the tracking of excess weight in different periods of life, with the view that this conduct may be an important strategy in combating overweight.

The occurrences of excess weight determined in this study in 2002 and 2005 were high; $29 \%$ and $27.5 \%$ of subjects were considered as presenting excess weight, respectively. The increase in excess weight may be associated with a number of causes, among which are a marked reduction in levels of daily physical activity and inadequate eating habits. Another factor that may have contributed to these results is the socioeconomic level of the sample studied. Other studies involving samples of Brazilian children with the same socioeconomic characteristics found rates of excess weight close to those of the present study with variations between 26 and $28 \%{ }^{10}$.

Although we did not control for dietary habits and habitual physical activity levels, it is believed that some of our results can be explained by these factors, since many young people have reduced their time in moderate or vigorous physical activity practices and increased involvement in sedentary activities and, consequently, low energy expenditure, such as watching television, excessive use of the internet, and playing video games or other electronic games during leisure and free time ${ }^{19}$.

No significant differences were observed in the proportions of subjects who were classified as having excess weight between the two moments, suggesting that in the interval of four years there was maintenance of the subjects in the excess weight category. This can be partially confirmed by the high correlations (ICC) of the continuous BMI values between the two moments, for both boys and girls. Despite the increase in the mean BMI values of the individuals between the moments, during the so-called adiposity rebound period ${ }^{20}$, this behavior was not able to alter the relative position of the subject within the group, indicating high tracking for BMI.

According to the recommendation for the interpretation of tracking, proposed by Malina ${ }^{6}$, the continuous BMI value was considered high (ICC=0.87), indicating that the trajectories of the subjects over time were stable. A study with a sample of Italian children and adolescents 
also showed high correlation values ranging from 0.79 to 0.85 for boys and girls respectively ${ }^{21}$. Söric et al. ${ }^{3}$, identified tracking between the beginning and end of adolescence with adult age in the order of 0.55 and 0.61 respectively in Croatian Young people.

The percentage of tracking between 2002 and 2005 indicated the proportion of subjects who remained in the same category of classification (normal-normal weight and excess-excess weight), which was $87 \%$, being $88 \%$ and $86 \%$ for boys and girls, respectively, with a force of agreement (k) of 0.68 which, according to Altman ${ }^{17}$, is classified as good agreement. These findings indicate strong maintenance of the subjects in a category during the study and that the presence of excess weight remained between childhood and adolescence.

However, the percentage of subjects who changed category during the study was $6 \%$ for children who went from normal weight to excess weight, while 7\% moved in the reverse direction (excess weight - normal weight). These findings were somewhat unexpected, since rates of increased prevalence of excess weight in this period are consistent. Starc and Strel|22 indicated that the percentage of children who moved from normal weight at age seven to obesity at age 18 was 17\% in a sample of Slovenian children followed for 12 years. In the Bogalusa study, between childhood and adulthood, it was verified that $32.5 \%$ of subjects changed from normal weight to excess weight ${ }^{23}$.

Another important aspect regarding the tracking of excess weight indicates that this trajectory can be influenced by behavioral factors. Craigie et al. ${ }^{24}$ observed in a systematic review that the tracking of diet and physical activity were two modifiable and stable behaviors over time, indicating that they are determinant factors in the risk of obesity in adulthood. Another study with Australian children showed that consumption of sweetened beverages, fatty foods, insufficient consumption of fruits and vegetables, and increased time using a computer and watching TV increased the relative risk of remaining in the excess weight category compared to the normal weight category ${ }^{5}$.

Although the evidence found in the present study indicates high tracking for BMI values and strong maintenance of the subjects in the category of excess weight, some limitations were not controlled, such as the absence of a diet profile, physical activity measures, and family risk information. On the other hand, the strengths of the study are the longitudinal design, the monitoring of the same subjects over four years, the representativeness of the sample, and the quality control of the data obtained.

Finally, the tracking of excess weight observed between childhood and adolescence may indicate an increase in the maintenance of subjects in the categories of health risk, favoring the development of numerous metabolic dysfunctions such as cardiovascular diseases, hypertension, diabetes, and cancer, among many others between childhood and adolescence, demonstrating a tendency to persist into adulthood.

\section{CONCLUSIONS}

It was concluded that the tracking of nutritional status between the period of childhood and adolescence in high socioeconomic school students was high, indicating that the trajectories of the individual BMI values over time presented few crossover points, demonstrating high maintenance of the position of the subjects within a group during the follow-up period. It is also worth noting that this condition indicates the maintenance of the subjects in the classification of excess weight during this period, for both boys and girls, which may represent an important risk factor for this population.

Finally, it is suggested that other follow-up studies be conducted in Brazil, observing the tracking of habitual physical activity, physical fitness, and eating habits during the transition between childhood and adolescence.

\section{ACKNOWLEDGEMENTS}

The authors would like to thank the Conselho Nacional de Desenvolvimento Científico e Tecnológico (CNPq) for the research productivity grant (E.R.V.R) and the Coordenação de Aperfeiçoamento de Pessoal de Nível Superior (CAPES) for the master's grants awarded (M.B.B.; M.R.O.B.; J.C.C.).

All authors declare no potential conflict of interest related to this article.

AUTHORS' CONTRIBUTIONS: Each author made significant individual contributions to this manuscript. TGP (0000-0001-5703-527X)* and JCC (0000-0003-1398-0901)* were the main contributors in the writing of the manuscript, contributing substantially to the conception, interpretation of data for the work and review of the work. MROB (0000-0002-31602501)*: contributed to the writing and review of the manuscript. MBB (0000-0002-2513-9354)** contributed to the intellectual concept, the writing and review of the manuscript. MR $(0000-0003-1355-331 X)^{*}$ contributed to the intellectual concept and the review of the manuscript. ERVR (0000-0003-3430-3993)* writing of the article, statistical analysis, intellectual concept of the article, production of the entire research project and final approval of the manuscript version. ${ }^{*} \mathrm{ORCID}$ (Open Researcher and Contributor ID).

\section{REFERÊNCIAS}

1. WHO. Obesity and overweight [Internet]. 2015 [citado 20 de maio de 2008]. Recuperado de: http:// www.who.int/mediacentre/factsheets/fs311/en.

2. Falaschetti E, Hingorani AD, Jones A, Charakida M, Finer N, Whincup P, et al. Adiposity and cardiovascular risk factors in a large contemporary population of pre-pubertal children. Eur Heart J. 2010;31 (24):3063-72.

3. Soric M, Jembrek Gostovi M, Gostovi M, Hočevar M, Mišigoj-Durakovi M. Tracking of BMI, fatness and cardiorespiratory fitness from adolescence to middle adulthood: the Zagreb Growth and Development Longitudinal Study. Ann Hum Biol. 2014;41(3):238-43.

4. Kristiansen AL, Bjelland M, Brantsæter AL, Haugen M, Meltzer HM, Nystad W, et al. Tracking of body size from birth to 7 years of age and factors associated with maintenance of a high body size from birth to 7 years of age - the Norwegian Mother and Child Cohort study (MoBa). Public Health Nutr. 2014;18(10):1746-55.

5. Wheaton N, Millar L, Allender S, Nichols M. The stability of weight status through the early to middle childhood years in Australia: a longitudinal study. BMJ Open. 2015;5(4):1-9.

6. Malina RM. Tracking of Physical Activity Across the Lifespan. Res Q Exerc Sports. 1996;67(3 Suppl):S48-57.

7. Flores LS, Gaya AR, Petersen RDS, Gaya A. Trends of underweight, overweight, and obesity in Brazilian children and adolescents. J Pediatr. 2013;89(5):456-61.

8. Instituto Brasileiro de Geografia e Estatística (IBGE). Pesquisa Nacional da Saúde do Escolar (PeNSE). Rio de Janeiro: Ciência \& Saúde Coletiva; 2012.

9. Mo-suwan L, Nontarak J, Aekplakorn W, Satheannoppakao W. Computer Game Use and Television Viewing Increased Risk for Overweight among Low Activity Girls: Fourth Thai National Health Examination Survey 2008-2009. Int J Pediatr. 2014;2014:1-6.

10. Fernandes RA, Christofaro DGD, Cardoso JR, Ronque EVR, Freitas Júnior IF, Kawaguti SS, et al. Socioeconomic status as determinant of risk factors for overweight in adolescents | Status socioeconômico como determinante de fatores de risco associados com o sobrepeso em adolescentes. Ciênc Saúde Coletiva. 2011;16(10):4051-7.

11. Wang Y, Monteiro C, Popkin BM. Trends of obesity and underweight in older children and adolescents in the United States, Brazil, Cinha and Russia. Am J Clin Nutr. 2002;75(6):971-7.

12. Miranda JMQ, Palmeira MV, Polito LFT, Brandão MRF, Bocalini DS, Figueira Junior AJ, et al. Prevalência de sobrepeso e obesidade infantil em instituições de ensino: Públicas vs. privadas. Rev Bras Med do Esporte. 2015;21(2):104-7.

13. Barbeta PA. Estatística aplicada a Ciência Sociais. 7 Ed. Florianopolis: Editora da UFSC; 1994.

14. Gordon CC, Chumlea WC, Roche AF. Stature, recumbent length, and weight. In: Lohman TG, Roche AF, Martorell R (Org.). Anthropometric standardization reference manual. Champaign: Human Kinetics Books; 1988. p. 3-8

15. Cole TJ, Bellizzi MC, Flegal KM, Dietz WH. Establishing a standard definition for child overweight and obesity worldwide: international survey. Bmj. 2000;320:1-6.

16. Malina RM. Adherence to Physical Activity from Childhood to Adulthood: A Perspective from Tracking Studies. Quest. 2001;53(1):346-55.

17. Altman DG. Practical Studies for Medical Research. London: Chapman \& Hall; 1991.

18. vonBonsdorff MB, Törmäkangas T, Rantanen T, Salonen MK, Osmond C, Kajantie E, et al. Early life body mass trajectories and mortality in older age: Findings from the Helsinki Birth Cohort Study. Ann Med. 2014;47(1):34-9.

19. Ortega FB, Konstabel K, Pasquali E, Ruiz JR, Hurtig-Wennlöf A, Mäestu J, et al. Objectively Measured Physical Activity and Sedentary Time during Childhood, Adolescence and Young Adulthood: A Cohort Study. PLoS One. 2013;8(4):1-9.

20. Dietz WH. Overweight in childhood and adolescence. N Engl J Med. 2004;350(9):855-7.

21. Toselli S, Brasili P, Di Michele R. Tracking of weight status and body fatness in Italian children. Eat Weight Disord. 2013;18(4):383-8.

22. Starc G, Strel J. Tracking excess weight and obesity from childhood to young adulthood: a 12-year prospective cohort study in Slovenia. Public Health Nutr. 2011;14(1):49-55.

23. Deshmukh-Taskar P, Nicklas TA, Morales M, Yang SJ, Zakeri I, Berenson GS. Tracking of overweight status from childhood to young adulthood: the Bogalusa Heart Study. Eur J Clin Nutr. 2006;60(1):48-57.

24. Craigie AM, Lake AA, Kelly AS, Adamson AJ, Mathers JC. Tracking of obesity-related behaviours from childhood to adulthood: A systematic review. Maturitas. 2011;70(3):266-84. 